Article

\title{
Comparison of Different Biofilter Media During Biological Bed Maturation Using Common Carp as a Biogen Donor
}

\author{
Mateusz Sikora *, Joanna Nowosad and Dariusz Kucharczyk (D) \\ Department of Ichthyology and Aquaculture, University of Warmia and Mazury, Al. Warszawska 117A, \\ PL 10-701 Olsztyn, Poland; nowosad.joanna@gmail.com (J.N.); darekk56@gmail.com (D.K.) \\ * Correspondence: sikora0404@gmail.com
}

Received: 3 December 2019; Accepted: 7 January 2020; Published: 15 January 2020

\begin{abstract}
This experiment analysed the operation of submerged and dripping biological filters with three types of filling: commercial fitting HXF12KLL (CF), two innovative polypropylene aggregates (PPA) and polyethylene screw caps for PET bottles (PSC). The experiment determined the time needed to reach full filter functionality at the maturation stage, the time needed to start successive stages of the nitrification process and the maximum concentration of each nitrogen compound in water in the recirculation systems. The filter operation characteristics after the maturation stage were also examined. These issues are crucial during the preparation and launch of new aquaculture facilities. A literature analysis indicated that the ability of biological filters to oxidise nitrogen compounds is affected by a number of factors. Studies conducted at various centres have covered selected aspects and factors affecting the effectiveness of biological filters. During this study, the model fish common carp (Cyprinus carpio) was used. The current experiment involved examination of biological filter maturation and operation during the carp fry rearing stage, which allowed the biofilter operation characteristics to be determined. At the third day of the experiment, the ammonium concentration reached approximately $3 \mathrm{mg} \mathrm{NH}_{4}-\mathrm{N} / \mathrm{dm}^{3}$. It remained at this level for 10 days and later decreased below $0.25 \mathrm{mg} \mathrm{NH}_{4}-\mathrm{N} / \mathrm{dm}^{3}$. The maximum nitrite concentration ranged from $11.7 \mathrm{mg} / \mathrm{dm}^{3}$ to $20.9 \mathrm{mg} \mathrm{NO}-\mathrm{N} / \mathrm{dm}^{3}$ within 9 to 20 days and later decreased with time. Nitrate concentrations were seen to increase during the experiment. The all applied biofilter media showed possibility to be used in commercial aquaculture systems.
\end{abstract}

Keywords: biofilter maturation; nitrogen compounds; recirculating aquaculture system (RAS)

\section{Introduction}

Annual fish and seafood consumption has been increasing steadily. The amount of fish and seafood obtained globally is limited and annual output has remained at 90 million tonnes for the past decade. For this reason, any increase in the amount of fish and seafood is associated with aquaculture and its dynamic growth. The production of aquaculture accounted for $44 \%$ of the total output in 2014 [1,2]. Installations used for animal production can be classified in regard to the degree of water recirculation: (1) open/flow-through systems, in which water is used once; (2) semi-open/semi-closed systems, in which water is used multiple times before being removed from the system, and (3) closed systems, in which only water loss is replenished. Higher degrees of water recirculation require more complex systems to purify it. RAS denotes technologies of repeated water reuse in a closed system. However, water loss in breeding systems needs to be replenished for multiple reasons, not only because of evaporation. To minimise the need for replenishing water loss, RAS systems are equipped with complex water treatment and purification systems, including mechanical and biological 
filters, UV sterilisation devices, water ozonation systems and others [3,4]. The most important of these systems are biological filters, which control toxic nitrogen species and are necessary for RAS operation [3-5]. The fast increasing of aquaculture production in RAS is not possible without new developed technologies. One of the main focuses is media for biofilters, upon which the effectiveness of nitrification is dependant. This also an influence of biofilter costs, so new and cheaper biofilter media are necessary to involve in further aquaculture production growth [1-5].

The removal of toxic nitrogen from water is affected by nitrification, consisting of the biological oxidation of ammonium nitrogen to nitrite (III) nitrogen, followed by oxidation of the latter to nitrate (V) nitrogen. A crucial role in the nitrification process is played by Nitroso- (oxidation of ammonium to nitrite) and Nitro- (oxidation of nitrite to nitrate) nitrification bacteria [6,7]. Total ammonium nitrogen (TAN) is one of the major limiting factors in the design and operation of RAS systems [8] and is one of the metabolites which is formed in the digestion of proteins and the transformation of amino acids [9] given to fish with feed. It occurs as a sum of two species: dissociated (ammonium ion, $\mathrm{NH}_{4}{ }^{+}$) and undissociated (ammonia, $\mathrm{NH}_{3}$ ) $[8,10]$. Ammonium nitrogen in its dissociated form is relatively non-toxic, whereas the undissociated form is highly toxic $[8,9,11-17]$. For this reason, it must be controlled [17] and removed from the system or oxidised to a less toxic nitrogen form [8,18]. Ammonia levels in RAS systems are controlled by nitrification [17]. The $\mathrm{NH}_{4}{ }^{+} / \mathrm{NH}_{3}$ ratio depends mainly on the environment's $\mathrm{pH}$. The amount of toxic $\mathrm{NH}_{3}$ increases along with higher $\mathrm{pH}$, depending on the temperature, pressure and salinity. Excessive amounts of ammonia lead to tremors in fish, coma and death [10]. The ammonia removal process is affected by a number of factors. The most important of them is the availability of oxygen ( $4.57 \mathrm{~g}$ of oxygen is needed to oxidise $1 \mathrm{~g}$ of ammonium nitrogen) and the rate of its diffusion into the biomembrane [8]. A decrease in water saturation with oxygen results in inhibition of ammonium nitrogen oxidation $[19,20]$. Important factors also include temperature, $\mathrm{pH}$, salinity and organic matter burden on the biological filter [8]. Nitrite nitrogen are intermediate compounds in nitrification [6,7]. Due to their toxic effect on fish, they are an equally important factor in fish breeding as ammonium nitrogen $[7,14,21,22]$ and are responsible for chronic diseases leading to fish death [7]. Nitrate nitrogen is the last step in the nitrification process [6,7] and has long been regarded as harmless. Recent studies have shown that it should be taken into account when optimising fish breeding. This nitrogen form is relatively harmless, but long-term exposure is suspected of having deadly toxic effects [21,23], although further studies are needed [23]. Analysis of the nitrification process gives the information if the biofilter is matured. In RAS equipped with such a biofilter, the level of ammonium and nitrite concentrations are low and stable [18]. It is especially important for finfish species, which are sensitive to toxic nitrogen compounds, like salmonids $[4,6,7,11,12]$.

The kinetics of the reaction were not studied during the experiment, because the purpose of the study was to examine whether the applied experimental fillers for biological filters are useful in aquaculture. The reaction kinetics study is the next step after confirming the suitability of the filling used. The operation of modern aquaculture systems and their further dynamic growth requires the continuous development of new technologies [24]. It is equally important to keep in mind while developing new technologies or solutions that biological filter operation is affected by a number of factors, e.g., dissolved oxygen and the rate of its diffusion into the biomembrane, temperature, $\mathrm{pH}$, salinity and organic matter burden on the biological filter, which is not always reflected in laboratory tests [7,25-27]. Considering the above, a two-step experiment was conducted on a semi-commercial scale, in which submerged and dripping biological filters with three different fillings were used, which are different from each other. CFs (commercial fitting HXF12KLL) have been designed to obtain the largest possible area in a unit of volume. In addition, their spatial structure allows the free flow of water through the centre of individual fittings, which effectively supports nitrification (nitrifiers have constant access to nitrogen compounds). PSCs (polyethylene screw caps for PET bottles) have more than three times smaller surface area per unit volume, but due to their shape, the inflow of nitrogen compounds to the biofilm is greatly facilitated. PPAs (polypropylene aggregate) have the least regular shape. A microscopic photograph reveals a lack of internal spaces on which a bacterial biofilm could 
develop. However, the outer structure has numerous recesses and protrusions, which are very diverse and provide favourable conditions for the development of nitrifiers. The main donor of nitrogen compounds were common carp Cyprinus carpio juveniles. The study examined the dynamics of nitrogen compound transformations during biological bed maturation and matured bed operation. Moreover, increasing the daily nutrient dose allowed the bed operation to be examined with increasing loads.

A system with submerged filters with commercial fillings was used as a control. During the experiment, the hypothesis was verified that the use of polypropylene aggregate and polyethylene screw caps for PET bottles as fillers for biological filters will achieve the same effects as the use of commercial fittings HXF12KLL.

\section{Materials and Methods}

The experiment lasted 60 days in the submerged biological bed variant (two days of fish acclimatisation and 58 days of the water parameter measurements) using tap water. The experiment lasted 45 days in the dripping biological bed variant (two days of fish acclimatisation and 43 days of the water parameter measurements). The biological bed maturated during this time, which allowed the dynamics of nitrogen compound transformations in a maturated bed system to be examined. Moreover, increasing the daily nutrient dose allowed the bed operation to be examined with an increasing load. Ammonium, nitrites and nitrates' concentration in tap water at the beginning of the experiment was $0.045 \mathrm{mg} \mathrm{N}-\mathrm{NH}_{4} / \mathrm{dm}^{3}, 0.027 \mathrm{mg} \mathrm{N}-\mathrm{NO}_{2} / \mathrm{dm}^{3}$ and $0.872 \mathrm{mg} \mathrm{N}-\mathrm{NO}_{3} / \mathrm{dm}^{3}$.

\subsection{Experimental Conditions}

\subsubsection{RAS Systems}

The experiment was conducted in four identical semi-open RAS systems with $625 \mathrm{dm}^{3}$ volumes each (daily refill-150 $\mathrm{dm}^{3}$ ) modelled on devices used by Sikora et al. [18]. Three types of biological filter fillings were examined:

- Polypropylene aggregate (PPA) (active surface area 300-500 $\mathrm{m}^{2} / \mathrm{m}^{3}$-manufacturer's data) (Figure 1A).

- $\quad$ Polyethylene screw caps for PET bottles (PSC) (active surface area ca. $300 \mathrm{~m}^{2} / \mathrm{m}^{3}$ ) (Figure 1B).

- Commercial fittings HXF12KLL (CF) (active surface area $859 \mathrm{~m}^{2} / \mathrm{m}^{3}$, Stöhr GmhH \& Co. KG, Marktrodach, Germany) (Figure 1C).

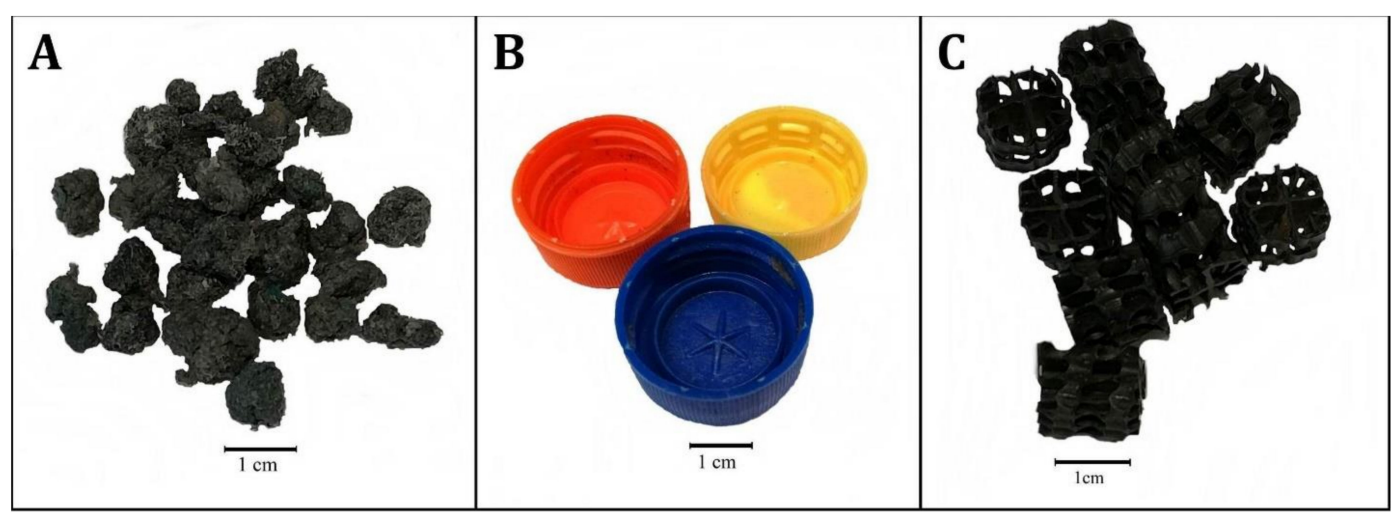

Figure 1. Polypropylene aggregate (PPA)-specifics surface area-ca. $12 \mathrm{~m}^{2}$ (A); polyethylene screw caps for PET bottles (PSC)-specifics surface area-ca. $9 \mathrm{~m}^{2}$ (B); Commercial fittings HXF12KLL (CF)-specifics surface area-ca. $25.5 \mathrm{~m}^{2}(\mathbf{C})$.

Each RAS system consisted of: an upper retention reservoir, a two-chamber lower retention reservoir (sedimentation chamber, pump chamber) and two rearing tanks. The systems were also fitted out with heaters, thermostats and aeration systems. The biological filter filling volume was 
$30 \mathrm{dm}^{3}$. The specifics surface area of the biological filters used was: PPA—ca. $12 \mathrm{~m}^{2}$, PSC - ca. $9 \mathrm{~m}^{2}$, $\mathrm{CF}-$ ca. $25.5 \mathrm{~m}^{2}$. For submerged filters (Figure 2), the filling was placed directly in the sedimentation chamber. The filling was suspended above the sedimentation chamber in the variant with dripping filter (Figure 3), which had sprinklers mounted above them.

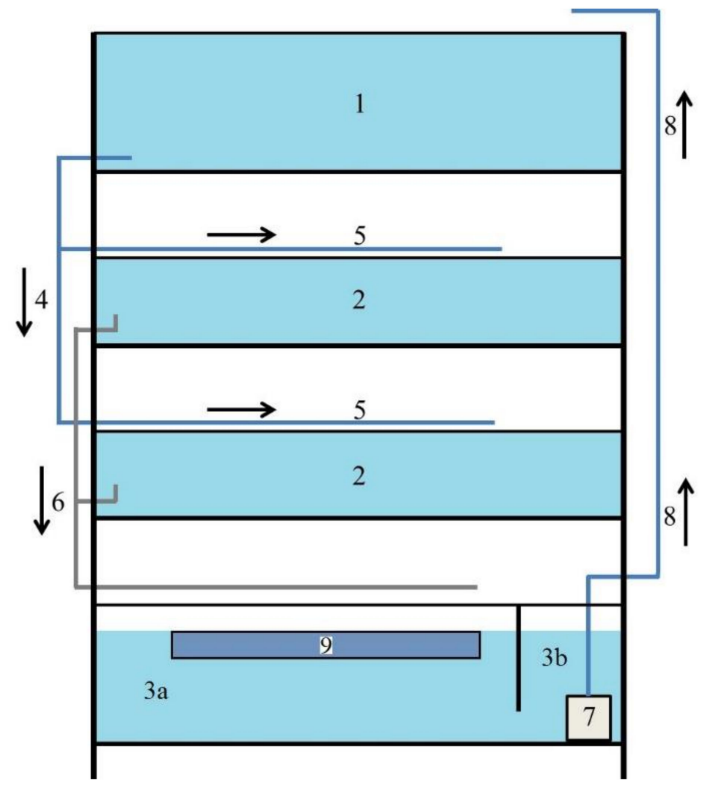

Figure 2. Recirculation aquaculture system with submerged filter scheme: 1 upper retention tank-0.251 $\mathrm{m}^{3}, 2$ rearing tank-2 $\times 0.096 \mathrm{~m}^{3}, 3$ lower retention tank (3a chamber with biofilter, $3 \mathrm{~b}$ chamber with pump) $-0.182 \mathrm{~m}^{3}, 4$ water inlets, 5 sprinklers, 6 water outlets, 7 pump, 8 water supply to upper retention tank, 9 submerged filter- $-0.030 \mathrm{~m}^{3}$.

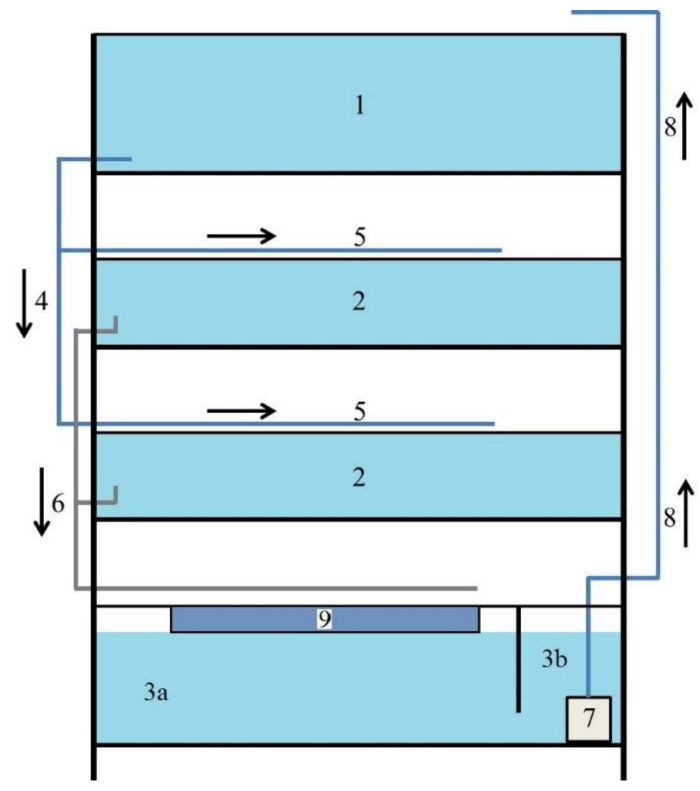

Figure 3. Recirculation aquaculture system with dripping filter scheme: 1 upper retention tank-0.251 $\mathrm{m}^{3}, 2$ rearing tank-2 $\times 0.096 \mathrm{~m}^{3}, 3$ lower retention tank (3a chamber with biofilter, 3b chamber with pump) - $0.182 \mathrm{~m}^{3}, 4$ water inlets, 5 sprinklers, 6 water outlets, 7 pump, 8 water supply to upper retention tank, 9 dripping filter- $0.030 \mathrm{~m}^{3}$.

The systems were started five days before the fish were put in them to stabilise the conditions in the recirculation systems. The circulating water temperature was $25.0 \pm 0.1{ }^{\circ} \mathrm{C}$. Before the experiment, 
the systems were first thoroughly dried, disinfected with potassium permanganate at $7.5 \mathrm{~g}$ per run and then rinsed with water from the water supply system for $24 \mathrm{~h}$.

\subsubsection{Fish}

Common carp juvenile (Cyprinus carpio), bred at the Department of Lake and River Fisheries of the University of Warmia and Mazury in Olsztyn and cultured under controlled conditions, were used in all experiment as a source of nitrogen compounds. Out-of-season carp breeding was carried out in accordance with the methodology described by Kucharczyk et al. [28], with the insemination method modified by Kucharczyk et al. [29] for burbot (Lota lota), ide (Leuciscus idus) and asp (Aspius aspius). The carp larvae were reared in a recirculation system at $25 \pm 0.1^{\circ} \mathrm{C}$ and fed brine shrimp (Artemia salina) nauplii for the first 25 days. Artificial feed with a granulation of 0.5-1.1 (Skretting, Norway: raw protein content $54 \%$, fat content $18 \%$ ) was introduced after that time.

In the submerged biological bed variant, $1379 \pm 49 \mathrm{~g}$ (average \pm SD) of fry with a weight and unit length of $3.76 \pm 1.55 \mathrm{~g}$ (average $\pm \mathrm{SD}$ ) and $59.00 \pm 8.77 \mathrm{~mm}$ (average $\pm \mathrm{SD}$ ) were placed in the RAS systems. In the dripping biological bed variant, however, $1400.00 \pm 0.00 \mathrm{~g}$ fry with a unit weight and length of $16.30 \pm 4.80 \mathrm{~g}$ and $96.40 \pm 9.65 \mathrm{~mm}$ were placed in the RAS systems. All fish used during the experiment are juvenile forms of common carp.

The fish (carp) were fed twice daily (at 8.30 and 15.00) during the experiment with an artificial feed with a granulation of 1.1 (Skretting, Norway: raw protein content $54 \%$, fat content $18 \%$ ) and $1.9 \mathrm{~mm}$ (Skretting, Norway: raw protein content 50\%, fat content 20\%), with a single feeding lasting $30 \mathrm{~min}$. The feeding dose was set at $3 \%$ of the daily biomass (half of the daily feeding dose was provided in one feeding). Subsequently, the dose was increased daily by $3 \%$ of the initial fish biomass $[30,31]$. The initial daily feed dose was $20.9 \pm 0.5 \mathrm{~g}$ (average $\pm \mathrm{SD}$ ).

Sodium chloride was added to circulating water beginning on the day the nitrite nitrogen concentration reached $1 \mathrm{mg} \mathrm{N}-\mathrm{NO}_{2} / \mathrm{dm}^{3}$. Nitrite shows of affinity to the $\mathrm{Cl}^{-} / \mathrm{HCO}_{3}{ }^{-}$ion exchange. As a result, a part of the nitrite is taken up by fish instead of chloride. Increase of chloride concentration in the water reduces nitrite uptake by fish [32].

\subsection{Water Quality Measurements}

Water tests started two days after the fish were placed in the systems. The water in each system was examined at 11:00 (samples were taken from the sprinkler). Hach Lange cuvette tests with a dedicated DR 5000 spectrophotometer were used for the water testing [18]:

Ammonium—cuvette test LCK 304

Nitrite-cuvette test LCK 341

Nitrate-cuvette test LCK 340

Daily ammonium assays were conducted for the initial 17 days of the experiment. The aim of this test was to check whether the compound accumulates in the water in excessive amounts. After that time, measurements were conducted every three days to monitor the total ammonium concentration in the circulating water. The nitrite concentration was checked daily throughout the experiment to determine the time needed to start stage I of nitrification (oxidation of ammonia to nitrites). The nitrate concentration in the water was tested daily for the first 28 days, after which measurements were conducted every two days to determine the time needed to start stage II of nitrification (oxidation of nitrite nitrogen to nitrate nitrogen).

Moreover, the following water parameters in the bed were measured at 11.00:

- $\quad \mathrm{pH}$ - using a portable $\mathrm{pH}$-meter manufactured by Oxyguard,

- $\quad$ Oxygen concentration ( $\mathrm{mg} \mathrm{O}_{2} / \mathrm{dm}^{3}$, saturation)—using an oxygen probe, a portable Polaris 2 manufactured by Oxyguard,

- Temperature- using an oxygen probe, a portable Polaris 2 manufactured by Oxyguard, 
Moreover, the following water parameters were tested before the morning and afternoon feeding:

- Temperature-a probe combined with a thermostat controlling heater work,

- $\quad \mathrm{pH}$ - using a portable $\mathrm{pH}-$ meter manufactured by Oxyguard,

- Oxygen concentration ( $\mathrm{mg} \mathrm{O}_{2} / \mathrm{dm}^{3}$, saturation) - using an oxygen probe, connected with the Total Commander system manufactured by Oxyguard.

\subsection{Fish Measurements}

The fish were measured (average weight and average total length) at the beginning and end of the experiment. Thirty fish were collected randomly and weighed with an analytical balance (KERN \& Sohn $\mathrm{GmbH}$, Balingen, Germany) with an accuracy of $0.1 \mathrm{mg}$. The fish body lengths were measured with a calliper MEGA 20513 (Profix, Warsaw, Poland) with an accuracy of $0.01 \mathrm{~mm}$. Due to the fish size, their bodies were measured after the experiment with a ruler with an accuracy of $1 \mathrm{~mm}$. Moreover, the fish biomass was determined at both the beginning and end of the experiment (analytical balance KERN \& Sohn GmbH, Germany). The fish were anaesthetised during the measurements with an MS222 anaesthetic at a concentration of $50 \mathrm{ppm}$.

\subsection{Statistical Analysis}

The dynamics of nitrogen compound (ammonia, nitrites, nitrates) transformations were examined with a Kruskal-Wallis ANOVA test on ranks $(p>0.05)$ and subsequently by multiple comparisons of mean ranks $(p>0.05)$ for all samples. The distribution normality was verified with the Shapiro-Wilk test $(p>0.05)$ before the ANOVA test was performed. All results were analysed statistically using Statistica 13.1 software (StatSoft, Tulsa, Oklahoma, USA). In addition, in order to analyse the nature of individual stages of nitrification, regression equations were performed and the correlation coefficient (R) was calculated.

\section{Results}

\subsection{Variant I-Use of Submerged Biological Filter}

\subsubsection{Ammonium Nitrogen}

At the beginning of the experiment, the ammonium concentration increased rapidly in all experimental RAS and was about $3 \mathrm{mg} \mathrm{N}-\mathrm{NH}_{4} / \mathrm{dm}^{3}$ from day 3 (Figure 4).

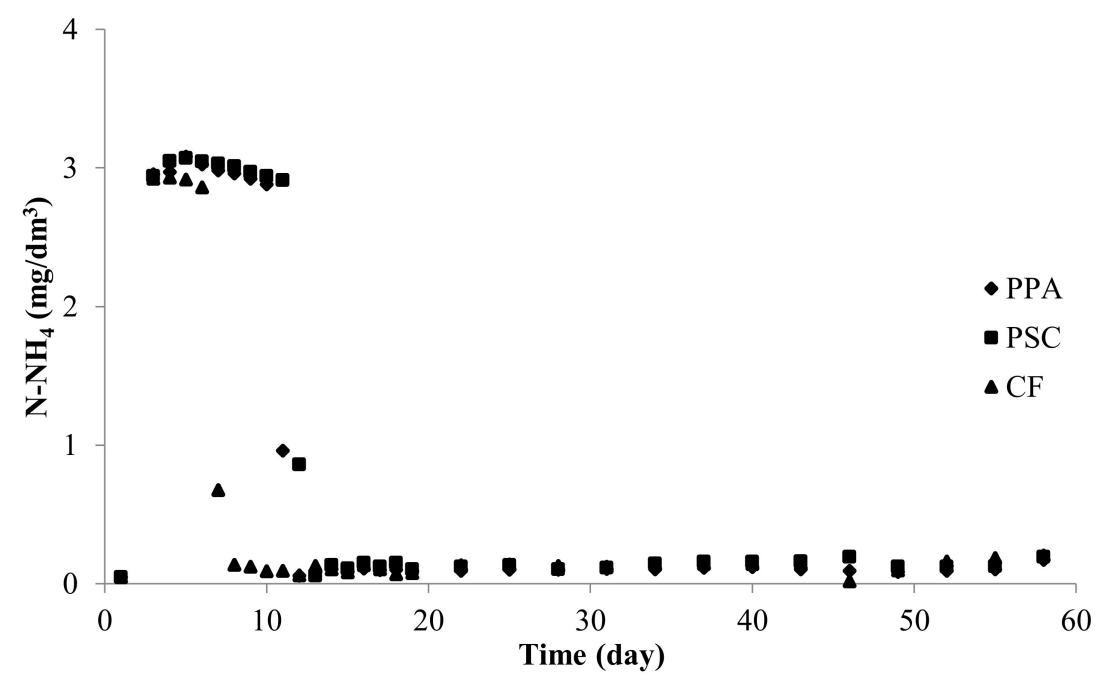

Figure 4. Ammonium nitrogen concentration in experimental systems using submerged biological filters: PPA—-polypropylene aggregate, PSC—-polyethylene screw caps for PET bottles, CF-commercial fittings HXF12KLL. 
High ammonia levels lasted for several days and then quickly decreased. After this period, until the end of the experiment, no major increases in ammonium were recorded in RAS circuits (Table 1).

Table 1. Ammonium nitrogen concentration in RAS, in which various tested fillings (PPApolypropylene aggregate, PSC — polyethylene screw caps for PET bottles, CF-commercial fittings HXF12KLL) were used for two separated stages, Stage I (high ammonium concentration) and Stage II (low concentrations ammonium) separated by a period of rapid drop in ammonium (break down).

\begin{tabular}{|c|c|c|c|c|}
\hline Filling & & Stage I & Break Down & Stage II \\
\hline \multirow{2}{*}{ PPA } & $\begin{array}{l}\text { Average } \pm \text { SD } \\
\left(\mathrm{N}-\mathrm{NH}_{4} / \mathrm{dm}^{3}\right)\end{array}$ & $2.971 \pm 0.059$ & 0.960 & $0.100 \pm 0.022$ \\
\hline & Duration (d) & $3-10$ & 11 & $12-60$ \\
\hline \multirow{2}{*}{ PSC } & $\begin{array}{l}\text { Average } \pm \text { SD } \\
\left(\mathrm{N}-\mathrm{NH}_{4} / \mathrm{dm}^{3}\right)\end{array}$ & $2.996 \pm 0.056$ & 0.860 & $0.133 \pm 0.031$ \\
\hline & Duration $(\mathrm{d})$ & $3-11$ & 12 & $13-60$ \\
\hline \multirow{2}{*}{$\mathrm{CF}$} & $\begin{array}{l}\text { Average } \pm \text { SD } \\
\left(\mathrm{N}-\mathrm{NH}_{4} / \mathrm{dm}^{3}\right)\end{array}$ & $2.906 \pm 0.029$ & 0,675 & $0.118 \pm 0.040$ \\
\hline & Duration (d) & $3-6$ & 7 & $8-60$ \\
\hline
\end{tabular}

\subsubsection{Nitrite Nitrogen}

In all RAS, nitrite levels increased for several dozen days until the maximum concentration was reached. After this time, the concentrations decreased until they reached a relatively low and stable level, which remained until the end of the experiment (Figure 5; Table 2).

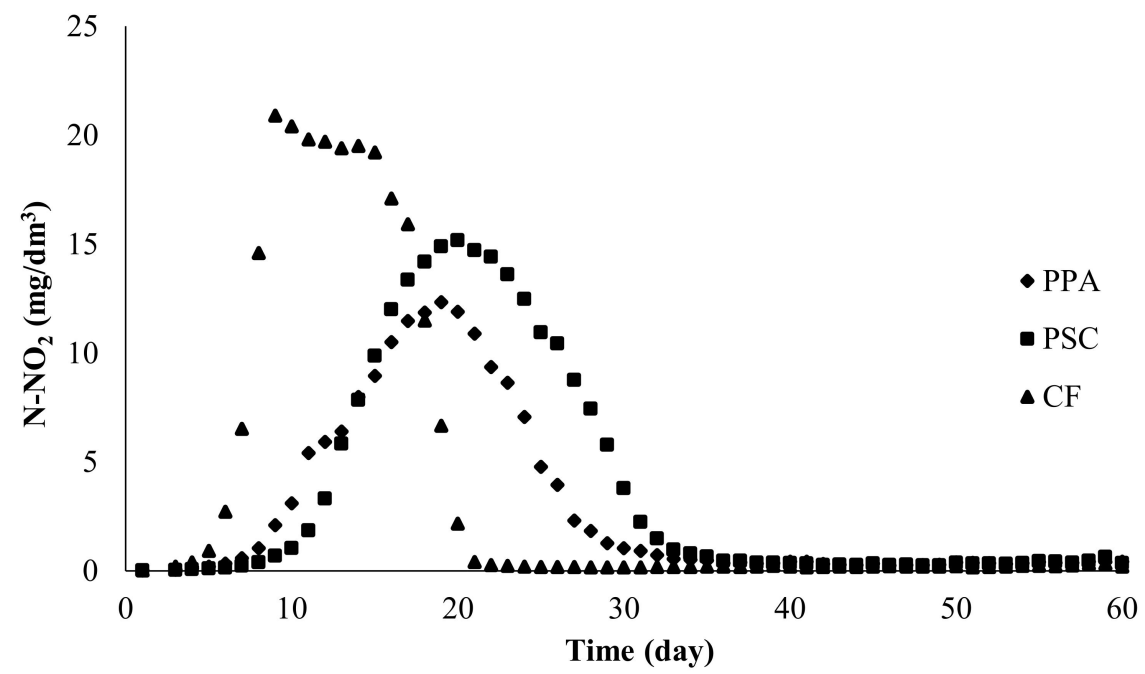

Figure 5. Nitrite nitrogen concentration in experimental systems using submerged biological filters: PPA-polypropylene aggregate, PSC - polyethylene screw caps for PET bottles, CF-commercial fittings HXF12KLL.

Table 2. Nitrite nitrogen concentration in RAS, in which various tested fillings (PPA-polypropylene aggregate, PSC - polyethylene screw caps for PET bottles, CF-commercial fittings HXF12KLL) were used for two separated stages, Stage I (high nitrite concentration) and Stage II (low nitrite concentration).

\begin{tabular}{cccccc}
\hline \multirow{2}{*}{ Filling } & \multicolumn{2}{c}{ Stage I } & \multicolumn{2}{c}{ Stage II } \\
\cline { 2 - 6 } & Increase (d) & $\begin{array}{c}\text { Maximum Concentration } \\
\left(\mathbf{N}-\mathbf{N O}_{\mathbf{2}} / \mathbf{d m}^{3}\right)\end{array}$ & Decrease (d) & $\begin{array}{c}\text { Average } \pm \text { SD } \\
\left(\mathbf{N}-\mathbf{N O}_{\mathbf{2}} / \mathbf{d m}^{\mathbf{3}} \mathbf{)}\right.\end{array}$ & Duration (d) \\
\hline PPA & $1-19$ & 12.340 & $19-31$ & $0.404 \pm 0.137$ & 14 \\
PSC & $1-20$ & 15.180 & $20-33$ & $0.412 \pm 0.169$ & 12 \\
CF & $1-9$ & 20.900 & $9-21$ & $0.211 \pm 0.049$ & 24 \\
\hline
\end{tabular}




\subsubsection{Nitrate Nitrogen}

The nitrate concentration in the system with PPA as the biological filter filling increased until day 53 and reached $32.05 \mathrm{mg} \mathrm{N}-\mathrm{NO}_{3} / \mathrm{dm}^{3}$. It began to decrease afterwards. A similar trend was observed in the other two experiment variants. The concentration in the PSC system also rose until day 53 to reach a similar level $\left(34.35 \mathrm{mg} \mathrm{N}-\mathrm{NO}_{3} / \mathrm{dm}^{3}\right)$. The highest concentration in the system with $\mathrm{CF}$ filling was higher than in the other two systems $\left(50.40 \mathrm{mg} \mathrm{N}-\mathrm{NO}_{3} / \mathrm{dm}^{3}\right)$ and it was measured during a shorter time (day 44) (Figure 6).

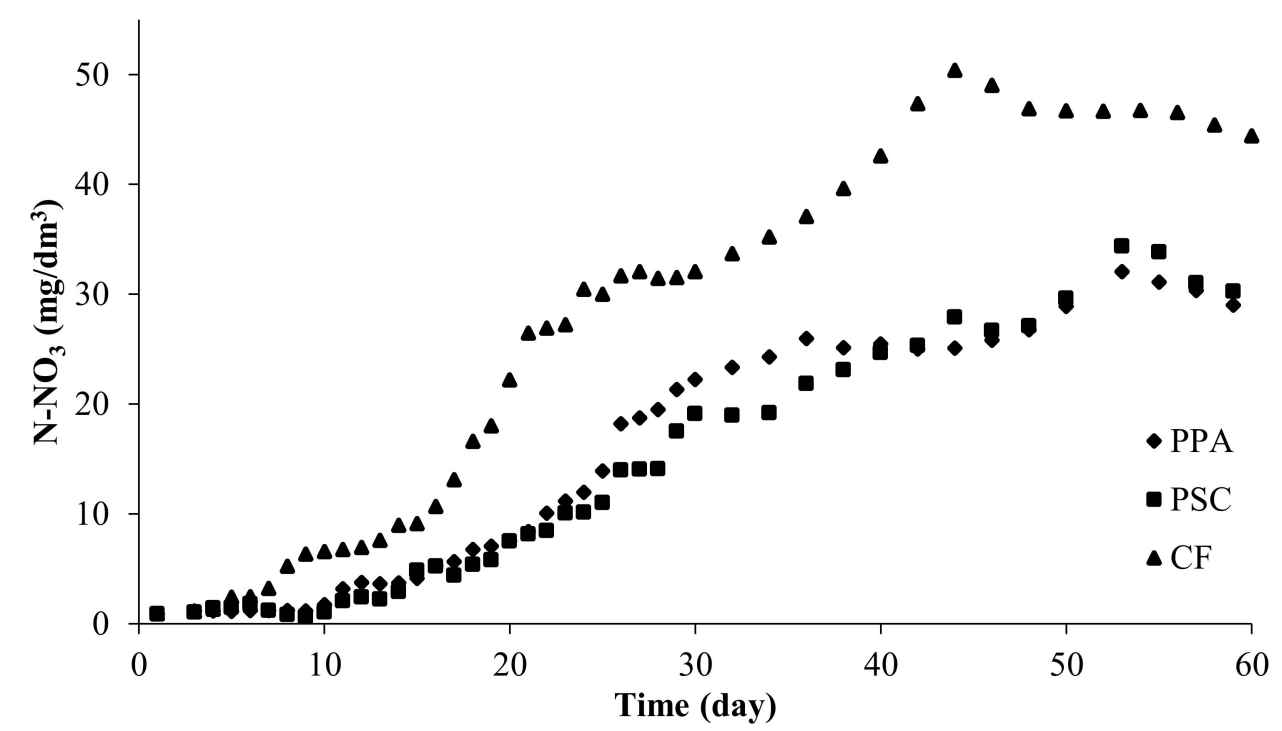

Figure 6. Nitrate nitrogen concentration in experimental systems using submerged biological filters: PPA-polypropylene aggregate, PSC—polyethylene screw caps for PET bottles, CF-commercial fittings HXF12KLL.

\subsubsection{Other Water Parameters}

The average water temperature in the system with PPA was $24.8 \pm 0.4^{\circ} \mathrm{C}$, average $\mathrm{pH}-8.01 \pm 0.15$, whereas the average concentration of oxygen dissolved in water and saturation were $6.6 \pm 0.7 \mathrm{mg} \mathrm{O} / \mathrm{dm}^{3}$ and $79.8 \pm 8.7 \%$, respectively. The same parameters in the PSC system were: water temperature $24.8 \pm 0.3{ }^{\circ} \mathrm{C}, \mathrm{pH} 8.03 \pm 0.15$, dissolved oxygen concentration $6.7 \pm 0.7 \mathrm{mg} \mathrm{O}_{2} / \mathrm{dm}^{3}$, saturation $82.4 \pm 8.6 \%$. In the system with CF filling, the parameters were: water temperature $24.8 \pm 0.6{ }^{\circ} \mathrm{C}$, $\mathrm{pH} 8.06 \pm 0.14$, dissolved oxygen concentration $6.8 \pm 0.6 \mathrm{mg} \mathrm{O}_{2} / \mathrm{dm}^{3}$ and saturation $81.6 \pm 7.2 \%$.

\subsection{Variant II-Use of Dripping Filters}

The system with a submerged filter with CF filling (CFsf) was used again as the control in the second part of the experiment with dripping filters. There was a failure and leak in the system with the dripping filter filled with $\mathrm{CF}$ during this part of the experiment. The system was restarted in accordance with the procedure presented in the methodology.

\subsubsection{Ammonium Nitrogen}

As in the case of submerged filters, the concentration of ammonium in the experimental RAS systems increased rapidly and from day 3 it was about $3 \mathrm{mg} \mathrm{N}-\mathrm{NH}_{4} / \mathrm{dm}^{3}$ (Figure 7). 


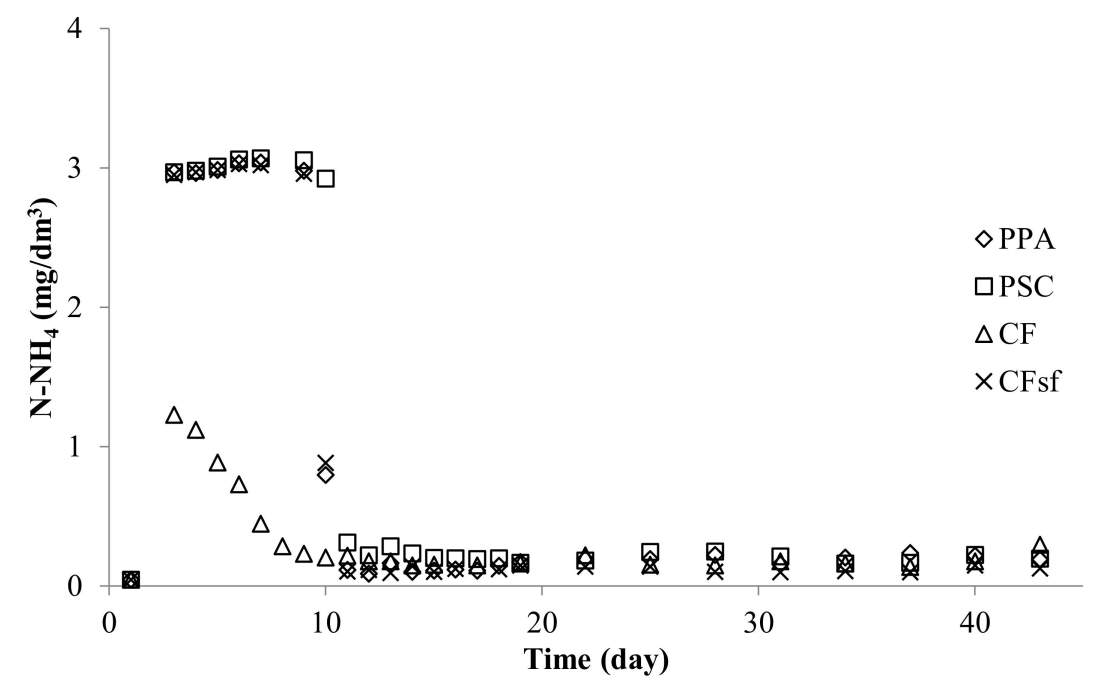

Figure 7. Ammonium nitrogen concentration in experimental systems using dripping biological filters: PPA - polypropylene aggregate, PSC - polyethylene screw caps for PET bottles, CF-commercial fittings HXF12KLL, CFsf-control submerged filter for dripping filters, commercial fittings HXF12KLL.

High ammonia levels lasted for several days and then quickly decreased. After this period, no significant increases in RAS ammonium were noted until the end of the experiment (Table 3).

Table 3. Ammonium nitrogen concentration in RAS, in which test fillings (PPA-polypropylene aggregate, PSC — polyethylene screw caps for PET bottles, CFsf-control submerged filter for dripping filters, commercial fittings HXF12KLL) were used for two separated stages: Stage I (high ammonium concentration) and Stage II (low ammonium concentrations) separated by a period of rapid drop in ammonium concentration (break down).

\begin{tabular}{|c|c|c|c|c|}
\hline Filling & & Stage I & Break Down & Stage II \\
\hline \multirow{2}{*}{ PPA } & $\begin{array}{l}\text { Average } \pm \text { SD } \\
\left(\mathrm{N}-\mathrm{NH}_{4} / \mathrm{dm}^{3}\right)\end{array}$ & $2.996 \pm 0.033$ & 0.799 & $0.162 \pm 0.048$ \\
\hline & Duration & $3-9$ & 10 & $11-45$ \\
\hline \multirow[t]{2}{*}{ PSC } & $\begin{array}{l}\text { Average } \pm \text { SD } \\
\left(\mathrm{N}-\mathrm{NH}_{4} / \mathrm{dm}^{3}\right)\end{array}$ & $3.010 \pm 0.055$ & 0.313 & $0.209 \pm 0.033$ \\
\hline & Duration & $3-10$ & 11 & $12-45$ \\
\hline \multirow[t]{2}{*}{ CFsf } & $\begin{array}{l}\text { Average } \pm \text { SD } \\
\left(\mathrm{N}-\mathrm{NH}_{4} / \mathrm{dm}^{3}\right)\end{array}$ & $2.986 \pm 0.033$ & 0.884 & $0.120 \pm 0.019$ \\
\hline & Duration & $3-9$ & 10 & $11-45$ \\
\hline
\end{tabular}

Only in the system in which a failure occurred were other characteristics of ammonium concentrations noted. The highest concentration in the system with CF was recorded on day 3-1.230 mg N-NH $4 / \mathrm{dm}^{3}$-and it decreased afterwards. The ammonium concentration decreased below $0.3 \mathrm{mg} \mathrm{N}-\mathrm{NH}_{4} / \mathrm{dm}^{3}$ after day 8 and until the end of the experiment it fluctuated, with an average concentration of $0.188 \pm 0.047 \mathrm{mg} \mathrm{N}^{-N_{4}} / \mathrm{dm}^{3}$ (Figure 7).

\subsubsection{Nitrite Nitrogen}

In all RAS, nitrite levels increased for several dozen days, until the maximum concentration was reached. After this time, the concentrations decreased until they reached a relatively low and stable level, which remained until the end of the experiment (Figure 8; Table 4). 


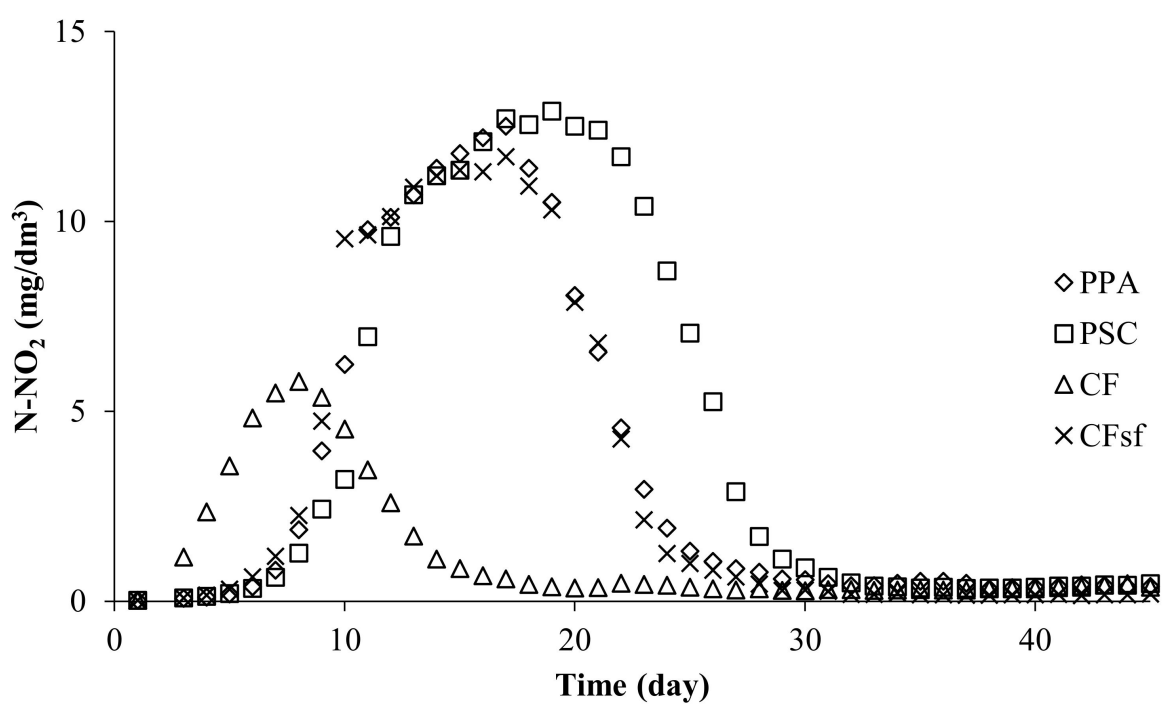

Figure 8. Nitrite nitrogen concentration in experimental systems using dripping biological filters: PPA—polypropylene aggregate, PSC—polyethylene screw caps for PET bottles, CF-commercial fittings HXF12KLL, CFsf-control submerged filter for dripping filters, commercial fittings HXF12KLL.

Table 4. Nitrite nitrogen concentration in RAS, in which test fillings (PPA-polypropylene aggregate, PSC-polyethylene screw caps for PET bottles, CF-commercial fittings HXF12KLL, CFsf-control submerged filter for dripping filters, commercial fittings HXF12KLL) were used for two separated stages: Stage I ((high nitrite concentration) and Stage II (low nitrite concentration).

\begin{tabular}{cccccc}
\hline & \multicolumn{3}{c}{ Stage I } & \multicolumn{2}{c}{ Stage II } \\
\cline { 2 - 6 } Filling & Increase (d) & $\begin{array}{c}\text { Maximum Concentration } \\
\left(\mathbf{N}-\mathbf{N O}_{\mathbf{2}} / \mathbf{d m}^{\mathbf{3}}\right)\end{array}$ & Decrease (d) & $\begin{array}{c}\text { Average } \pm \mathbf{S D} \\
\mathbf{( N - N O}_{\mathbf{2}} / \mathbf{d m}^{\mathbf{3}} \mathbf{)}\end{array}$ & Duration (d) \\
\hline PPA & $1-17$ & 12.500 & $17-27$ & $0.480 \pm 0.139$ & 18 \\
PSC & $1-19$ & 12.900 & $19-30$ & $0.438 \pm 0.137$ & 15 \\
CF & $1-8$ & 5.780 & $8-15$ & $0.385 \pm 0.126$ & 30 \\
CFsf & $1-17$ & 11.700 & $17-26$ & $0.261 \pm 0.178$ & 19 \\
\hline
\end{tabular}

\subsubsection{Nitrate Nitrogen}

The nitrate concentration in the system with PPA as the biological filter filling increased until day 44 and reached $32.150 \mathrm{mg} \mathrm{N}-\mathrm{NO}_{3} / \mathrm{dm}^{3}$. It decreased slightly afterwards. A similar trend was observed in the system with PSC. The highest concentration of $30.00 \mathrm{mg} \mathrm{N}-\mathrm{NO}_{3} / \mathrm{dm}^{3}$ was observed on day 40 and it decreased slightly afterwards. A different situation was observed in the system with CF. The concentration of nitrate nitrogen increased to $29.800 \mathrm{mg} \mathrm{N}-\mathrm{NO}_{3} / \mathrm{dm}^{3}$ on day 36; afterwards it decreased until the end of the experiment, reaching $25.00 \mathrm{mg} \mathrm{N}-\mathrm{NO}_{3} / \mathrm{dm}^{3}$ on the last day. In the system with CFsf, the nitrate concentration increased until day 32 and reached $32.15 \mathrm{mg} \mathrm{N}-\mathrm{NO}_{3} / \mathrm{dm}^{3}$ and it decreased slightly afterwards (Figure 9). 


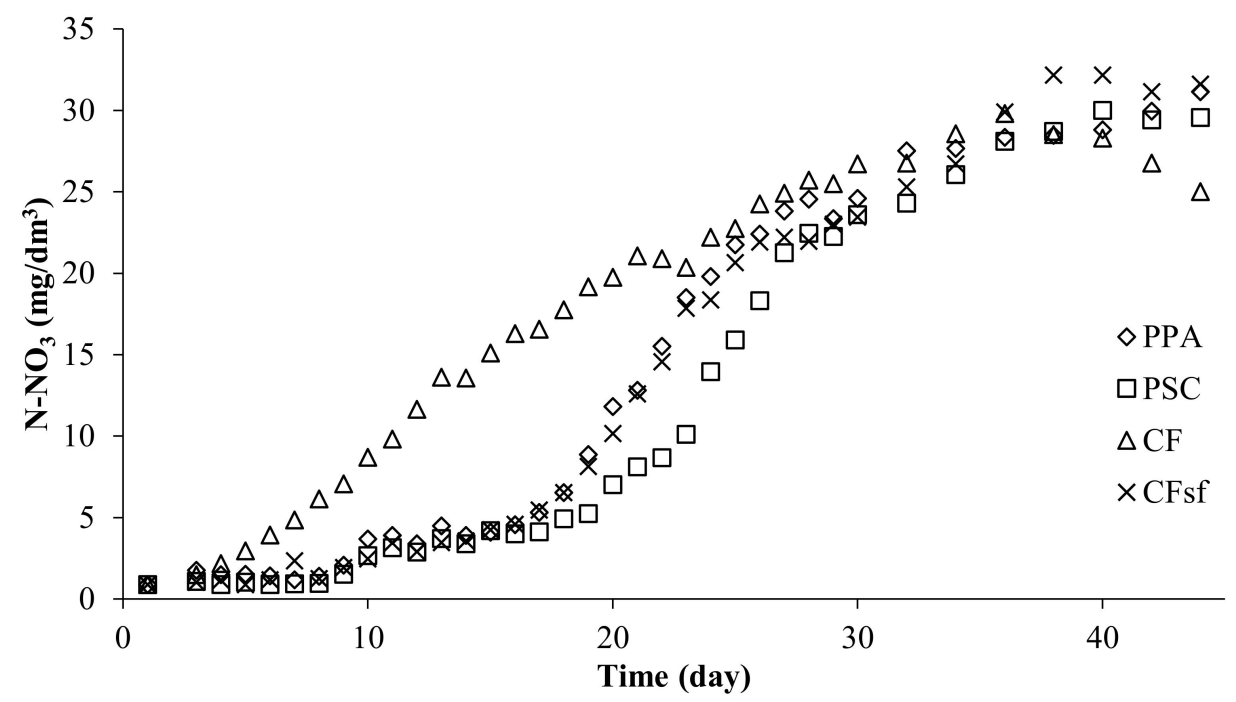

Figure 9. Nitrate nitrogen concentration in experimental systems using dripping biological filters: PPA-polypropylene aggregate, PSC - polyethylene screw caps for PET bottles, CF-commercial fittings HXF12KLL, CFsf-control submerged filter for dripping filters, commercial fittings HXF12KLL.

\subsubsection{Other Water Parameters}

The average water temperature in the system with PPA was $24.9 \pm 0.1^{\circ} \mathrm{C}$, average $\mathrm{pH}-8.84$ \pm 0.10 , whereas the average concentration of oxygen dissolved in water and saturation was $7.3 \pm$ $0.3 \mathrm{mg} \mathrm{O} / 2 \mathrm{dm}^{3}$ and $88.9 \pm 3.8 \%$, respectively. The same parameters in the system with PSC were: water temperature $24.9 \pm 0.2{ }^{\circ} \mathrm{C}, \mathrm{pH} 8.82 \pm 0.10$, dissolved oxygen concentration $7.5 \pm 0.4 \mathrm{mg} \mathrm{O} / / \mathrm{dm}^{3}$, saturation $92.1 \pm 3.9 \%$. In the system with $\mathrm{CF}$, the parameters were: water temperature $25.0 \pm 0.3$ ${ }^{\circ} \mathrm{C}$, pH $8.83 \pm 0.12$, dissolved oxygen concentration $7.0 \pm 0.4 \mathrm{mg} \mathrm{O}_{2} / \mathrm{dm}^{3}$ and saturation $85.7 \pm 4.7 \%$. The parameters in the control system (CFsf) were: water temperature $24.9 \pm 0.1{ }^{\circ} \mathrm{C}, \mathrm{pH} 8.74 \pm 0.15$, dissolved oxygen concentration $7.0 \pm 0.3 \mathrm{mg} \mathrm{O}_{2} / \mathrm{dm}^{3}$ and saturation $86.1 \pm 2.7 \%$.

\subsection{Statistical Analysis of Results}

The results do not have a normal distribution ( $p<0.05$, Shapiro-Wilk test). A statistical analysis of the results using a Kruskal-Wallis ANOVA rank test revealed significant differences between the RAS systems $(p<0.05)$. Detailed results are provided in the table (Table 5).

Table 5. Analysis of concentrations of nitrogen compounds using Kruskal-Wallis ANOVA test on ranks $(p>0.05)$ showed differences between individual RAS systems. Results of a multiple comparison test of mean ranks for all samples: PPA-polypropylene aggregate, PSC-polyethylene screw caps for PET bottles, CF-commercial fittings HXF12KLL, CFsf-control submerged filter for dripping filters, commercial fittings HXF12KLL. Data marked with the same letter in rows did not differ statistically.

\begin{tabular}{cccccccc}
\hline & \multicolumn{3}{c}{ Submerged Filter } & \multicolumn{7}{c}{ Dripping Filter } \\
\hline & PPA & PSC & CF & PPA & PSC & CF & CFsf \\
\hline Ammonium & a & b & a & bc & c & bc & ab \\
Nitrite & bcd & bcd & a & cd & d & abc & ab \\
Nitrate & bc & bc & a & b & c & ab & bc \\
\hline
\end{tabular}

Analysis of the results of ammonium concentrations in individual RAS allowed the determination of two periods of a different character for which regression equations take a different form. After placing the fish, the concentration of ammonium in individual systems increased. High levels of ammonium were noted from day 3, followed by low ones. There was one day of intermediate values between periods. Increases and decreases of ammonium concentration occurred rapidly. In the case of a system in 
which a failure occurred and it became necessary to restart it instead of a period with high concentrations, there was a period during which the concentration gradually decreased (Tables 1 and 3).

The analysis of nitrite concentration resulting in individual RAS allowed the determination of four periods with a different nature of the course. These periods for different RAS systems have a different duration but show a similar nature. In the first period, the regression equation describing the increase in concentration takes the form of an exponential function. In the second period, the concentration initially rose, reached the maximum level and began to decline and the equation takes a polynomial form. In the third period, characterized by a decrease in concentration, the equation takes on a power form. In the fourth period, nitrite concentrations remain at the same level without significant decreases or increases, and the equation again takes on a polynomial form (Table $6 a, b)$.

Table 6. (a) Nitrite nitrogen concentration analysis in experimental RAS systems using regress equation (Reg.) and correlation coefficients (R): PPA—polypropylene aggregate, PSC—polyethylene screw caps for PET bottles, CF-commercial fittings HXF12KLL, CFsf-control submerged filter for dripping filters, commercial fittings HXF12KLL. (b) Nitrite nitrogen concentration analysis in experimental RAS systems (dripping, CF) using regress equation (Reg.) and correlation coefficient (R).

\begin{tabular}{|c|c|c|c|c|c|}
\hline \multicolumn{6}{|c|}{ (a) } \\
\hline \multirow{2}{*}{$\begin{array}{l}\text { Type of Filter, } \\
\text { Filling }\end{array}$} & & \multicolumn{4}{|c|}{ Stage } \\
\hline & & I & II & III & IV \\
\hline $\begin{array}{l}\text { Submerged, } \\
\text { PPA }\end{array}$ & $\begin{array}{c}\text { Reg. } \\
\text { (R) } \\
\text { Duration (d) }\end{array}$ & $\begin{array}{c}y=0.0137 e^{0.5439 x} \\
0.9988 \\
1-11\end{array}$ & $\begin{array}{c}\mathrm{y}=-0.1324 \mathrm{x}^{2}+ \\
4.8955 \mathrm{x}-33.778 \\
0.9538 \\
11-24\end{array}$ & $\begin{array}{c}\mathrm{y}=6 \mathrm{E}+10 \mathrm{x}^{-7.218} \\
0.9916 \\
24-36\end{array}$ & $\begin{array}{c}y=0.0007 x^{2}- \\
0.0651 x+1.8372 \\
0.6644 \\
36-60\end{array}$ \\
\hline $\begin{array}{l}\text { Submerged, } \\
\text { PSC }\end{array}$ & $\begin{array}{c}\text { Reg. } \\
\text { (R) } \\
\text { Duration (d) }\end{array}$ & $\begin{array}{c}y=0.0117 e^{0.4586 x} \\
0.9894 \\
1-13\end{array}$ & $\begin{array}{c}y=-0.16 x^{2}+ \\
6.5599 x-52.287 \\
0.9909 \\
13-27\end{array}$ & $\begin{array}{c}y=5 E+16 x^{-10.96} \\
0.9931 \\
27-36\end{array}$ & $\begin{array}{c}y=0.0013 x^{2}- \\
0.1243 x+3.1995 \\
0.7628 \\
36-60\end{array}$ \\
\hline $\begin{array}{l}\text { Submerged, } \\
\text { CF }\end{array}$ & $\begin{array}{c}\text { Reg. } \\
\text { (R) } \\
\text { Duration (d) }\end{array}$ & $\begin{array}{c}\mathrm{y}=0.0115 \mathrm{e}^{0.8991 \mathrm{x}} \\
0.9991 \\
1-8\end{array}$ & $\begin{array}{c}\mathrm{y}=-0.24 \mathrm{x}^{2}+ \\
5.8161 \mathrm{x}-14.642 \\
0.9031 \\
8-18\end{array}$ & $\begin{array}{c}\mathrm{y}=7 \mathrm{E}+26 \mathrm{x}^{-20.47} \\
0.9817 \\
18-22\end{array}$ & $\begin{array}{c}\mathrm{y}=0.0002 \mathrm{x}^{2}- \\
0.0119 \mathrm{x}+0.4015 \\
0.6522 \\
22-60\end{array}$ \\
\hline $\begin{array}{l}\text { Dripping, } \\
\text { PPA }\end{array}$ & $\begin{array}{c}\text { Reg. } \\
\text { (R) } \\
\text { Duration (d) }\end{array}$ & $\begin{array}{c}\mathrm{y}=0.0109 \mathrm{e}^{0.6266 \mathrm{x}} \\
0.9953 \\
1-11\end{array}$ & $\begin{array}{c}y=-0.1126 x^{2}+ \\
3.5649 x-16.232 \\
0.9216 \\
11-19\end{array}$ & $\begin{array}{c}y=6 \mathrm{E}+09 x^{-6.821} \\
0.9914 \\
19-31\end{array}$ & $\begin{array}{c}\mathrm{y}=-0.0002 \mathrm{x}^{2}- \\
0.0057+0.4272 \\
0.4423 \\
31-45\end{array}$ \\
\hline $\begin{array}{l}\text { Dripping, } \\
\text { PSC }\end{array}$ & $\begin{array}{c}\text { Reg } \\
\text { (R) } \\
\text { Duration (d) }\end{array}$ & $\begin{array}{c}\mathrm{y}=0.0151 \mathrm{e}^{0.5446 \mathrm{x}} \\
0.9979 \\
1-12\end{array}$ & $\begin{array}{c}\mathrm{y}=-0.0698 \mathrm{x}^{2}+ \\
2.5974 \mathrm{x}-11.5 \\
0.9807 \\
12-22\end{array}$ & $\begin{array}{c}y=5 E+14 x-{ }^{9.983} \\
0.9913 \\
22-33\end{array}$ & $\begin{array}{c}y=0.002 x^{2}- \\
0.1489 x+3.1431 \\
0.9381 \\
33-45\end{array}$ \\
\hline $\begin{array}{l}\text { Submerged, } \\
\text { CFsf }\end{array}$ & $\begin{array}{c}\text { Reg. } \\
\text { (R) } \\
\text { Duration (d) }\end{array}$ & $\begin{array}{c}\mathrm{y}=0.0127 \mathrm{e}^{0.6536 \mathrm{x}} \\
0.9995 \\
1-10\end{array}$ & $\begin{array}{c}y=-0.0698 x^{2}+ \\
2.1765 x-5.6077 \\
0.9390 \\
10-19\end{array}$ & $\begin{array}{c}\mathrm{y}=2 \mathrm{E}+12 \mathrm{x}^{-8.719} \\
0.9914 \\
19-29\end{array}$ & $\begin{array}{c}\mathrm{y}=0.0013 \mathrm{x}^{2}- \\
0.1001 \mathrm{x}+2.1323 \\
0.9199 \\
29-45\end{array}$ \\
\hline \multicolumn{6}{|c|}{ (b) } \\
\hline Type of Filter, & & \multicolumn{4}{|c|}{ Stage } \\
\hline Filling & & I & II & III & \\
\hline $\begin{array}{l}\text { Dripping, } \\
\text { CF }\end{array}$ & $\begin{array}{c}\text { Reg. } \\
\text { (R) } \\
\text { Duration (d) }\end{array}$ & $\begin{array}{c}\mathrm{y}=-0.0351 \mathrm{x}^{3}+ \\
0.469 \mathrm{x}^{2}-0.8346 \mathrm{x}+ \\
0.4202 \\
0.9998 \\
1-9\end{array}$ & $\begin{array}{c}y=18770 x^{-3.647} \\
0.9917 \\
9-21\end{array}$ & $\begin{array}{c}y=0.001 x^{2}- \\
0.067 x+1.4065 \\
0.8223 \\
21-45\end{array}$ & \\
\hline
\end{tabular}

The concentration of nitrates in RAS systems show a similar tendency. After the initial slow increase in concentration, accelerated growth followed and was then inhibited. An analysis of the obtained results showed a decrease in nitrate concentration at the end of the experiment, which is reflected in the derived regression equations (Table 7). 
Table 7. Nitrate nitrogen concentration analysis in each experimental system using regress equation and correlation coefficients (R): PPA—polypropylene aggregate, PSC—polyethylene screw caps for PET bottles, CF-commercial fittings HXF12KLL, CFsf-control submerged filter for dripping filters, commercial fittings HXF12KLL.

\begin{tabular}{|c|c|c|}
\hline $\begin{array}{l}\text { Type of Filter, } \\
\text { Filling }\end{array}$ & Regress Equation & $\begin{array}{l}\text { Correlation } \\
\text { Coefficients (R) }\end{array}$ \\
\hline $\begin{array}{l}\text { Submerged, } \\
\text { PPA }\end{array}$ & $y=-0.0005 x^{3}+0.0392 x^{2}-0.1142 x+0.135$ & 0.9844 \\
\hline $\begin{array}{l}\text { Submerged, } \\
\text { PSC }\end{array}$ & $y=-0.0005 x^{3}+0.0425 x^{2}-0.3631 x+1.5747$ & 0.9946 \\
\hline $\begin{array}{l}\text { Submerged, } \\
\text { CF }\end{array}$ & $y=-0.0006 x^{3}+0.0367 x^{2}+0.5992 x-2.1153$ & 0.9797 \\
\hline $\begin{array}{l}\text { Dripping, } \\
\text { PPA }\end{array}$ & $y=-0.0017 x^{3}+0.1118 x^{2}-1.1623 x+3.931$ & 0.9884 \\
\hline $\begin{array}{l}\text { Dripping, } \\
\text { PSC }\end{array}$ & $y=-0.0015 x^{3}+0.1082 x^{2}-1.3589 x+4.808$ & 0.9882 \\
\hline $\begin{array}{l}\text { Submerged, } \\
\text { CFsf }\end{array}$ & $y=-0.0005 x^{3}+0.0174 x^{2}+0.9072 x-1.355$ & 0.9968 \\
\hline $\begin{array}{l}\text { Dripping, } \\
\text { CF }\end{array}$ & $y=-0.0015 x^{3}+0.1052 x^{2}-1.1256 x+3.7311$ & 0.9926 \\
\hline
\end{tabular}

\subsection{Fish}

During the experiment, no mortality was observed in the reared fish.

\section{Discussion}

In the experiment, the dynamics of changes in nitrogen compounds in the water used for rearing fish in semi-closed RAS were analysed in detail. The dynamics of nitrogen compounds (ammonium, nitrite, nitrate) during the maturation of biological filters as well as during the operation of mature filters were examined. Furthermore, the usefulness of PPA and PSC as fillings for biological filters was demonstrated. Due to the differences in construction, all three fillings have their own advantages and disadvantages. Therefore, when comparing fillings, the analysis was based on the analysis of changes in concentrations of nitrogen compounds in water and the time needed to achieve full filter functionality. Comparing structural parameters, especially similar in terms of the size of the active surface of PSC and PPA fillings, could be subjective. The impact of structural parameters should be examined at a later stage of the study, in which the impact of individual factors (e.g., oxygen, temperature, suspense solids, diffusion rate, etc.) would be analysed on the dynamics of the nitrification process. Water exchange is necessary in aquaculture farms using a closed water cycle equipped with biological filters without denitrification due to ever increasing level of nitrate. Denitrification is the process of reducing nitrates to gaseous nitrogen. It is an anaerobic process that can sometimes occur in biological filters overloaded by biogens. The amount of water needed varies depending on several factors. The most important is the increase in nitrate concentration, which in high concentrations shows adverse effects on aquatic organisms [21,23,33]. At the start-up stage of RAS facilities, water change is required for a similar reason. High concentrations of toxic forms of nitrogen occurring during the maturation of biological filters require the use of water changes not only to supplement evaporation. In the experiment, a one-time top-up of $150 \mathrm{dm}^{3}$ daily was used. This allowed for the dilution of nitrogen compounds and while supplementing calcium compounds in water, it also allowed better observation of the dynamics of nitrogen compound transformation processes. An important factor was also the use of common carp-a model species which is considered to be relatively resistant to adverse environmental rearing conditions [34].

Mechanical and biological filters must work together for the proper functioning of aquatic organisms $[7,26,27,35,36]$. The importance of the filtration process becomes significant when the breeding facility is built in RAS technology [22,37-42]. For the proper course of biological purification in the 
nitrification process, the cooperation of two groups of microorganisms is required. The first group oxidizes ammonia to nitrites and the other group oxidizes the formed nitrites to nitrates [6,7,43-45]. By analysing the concentration of particular forms of nitrogen in the water used during the commissioning of breeding facilities, it is possible to observe individual stages of nitrification and thus determine whether the biological filter has gained functionality $[18,45]$. The unpredictability of the maturation process was shown in an experiment carried out by Pulkkinen et al. [46] illustrating the effect of the type of biological filter used (fixed and moving bed bioreactors) on nitrification in recirculating aquaculture systems. In that experiment, despite the use of filter fillings operating for six months, the faulty operation of the bed was observed, which was revealed by an initially high concentration of nitrites, whose low level was achieved only after about eleven weeks. According to these authors, such a situation was caused by disturbances in the bacterial composition produced by the shock of transportation to a laboratory. This indicates the exceptional sensibility of nitrifying bacteria to variable environmental conditions. Due to the high concentration of toxic nitrogen compounds, fish rearing in circuits with immature biological filters threatens the loss of fish being reared. This is especially true for salmonids [47]. Therefore, species resistant to elevated concentrations of nitrogen compounds should be used at the start-up stage of aquaculture facilities.

The experiment using fish as a source of compounds needed in the nitrification process allowed observation of the work of the biological filter in conditions simulating real fish breeding [18]. Research carried out in this way is very important to properly carry out the maturation process of the biological filter and obtain a filter adapted to the given conditions in RAS systems. A review of the literature has shown that this approach to the topic is rare [18,48]. Research using synthetic solutions with nitrogen compounds dominates the field $[40,49,50]$. In this experiment, carp was used as a model species [34] with high metabolism [31].

During the experiment, all systems noted a rapid increase in the ammonium content in water to approximately $3 \mathrm{mg} \mathrm{N}-\mathrm{NH}_{4} / \mathrm{dm}^{3}$ (Figures 4 and 7; Tables 1 and 3). The increase in ammonium concentration resulted from placing the fish in the water cycle and starting feeding them. It should be emphasized that carp is a species with very high metabolism [31]. This level persisted from 4 days (submerged filter, CF) to 9 days (submerged filter, PSC) (Figure 4). In other filters, the duration of elevated ammonium concentration in the circuits was 7-8 days. After this period, there was a rapid, several-fold decrease in ammonium concentration in the RAS. It was assumed that the procedure involving the drying of the circuits and their disinfection through the use of potassium permanganate will eliminate nitrifying bacteria. The abrupt increase in ammonium has proved this assumption. Low concentrations persisted until the end of the experiment. In the system that was restarted, the distribution of ammonium concentrations was different (Figure 7). The first recorded results were about $60 \%$ lower than in other systems, and there was a rapid decrease in ammonium concentration. The fall curve was much milder. There is a discrepancy between the results obtained for two systems in which submerged filters filled with CF were used (Figures 4 and 7). The duration of elevated ammonium concentration for these systems was four days and eight days. The results during the experiment are divergent from the experiment carried out by Sikora et al. [18], in which no increase in ammonia concentration was observed. Kuhn et al. [45] reported similar results. In their research, they compared the effects of biological filters that were inoculated with nitrifying bacterial cultures with uninoculated filters. In unvaccinated RAS systems, ammonium nitrogen concentrations quickly rose above $2.5 \mathrm{mg} / \mathrm{dm}^{3}$ and then decreased. The time in which the ammonium nitrogen concentration was increasing and decreasing differed for the studied filters. The curves of changes in concentration were also different. In the case of filters inoculated with bacterial cultures, the course was similar to that observed in the system, which was restarted. This example supports the suggestion that nitrifying bacterial cultures remain in this system despite disinfection with potassium permanganate. For studies based on nitrifiers immobilized in PVA (polyvinyl alcohol) and then adapted to the salty environment [51], the time needed to remove the elevated TAN concentration (initial concentration of TAN introduced into bioreactors was $10 \mathrm{mg} / \mathrm{dm}^{3}$ ) to nitrite ranged from 22 days (salinity $30 \mathrm{ppt}$ ) 
to 26 days (salinity $7.5 \mathrm{ppt}$ ). These are longer periods than obtained during the author's experiment. In 2015, Hu et al. [52] conducted research on the removal of nitrogen compounds from tilapia culture (Oreochromis niloticus) using aquaponic crops (tomato Lycopersicon esculentum and pak choi Brassica campestris L. subsp. chinensis). In these studies, they used root systems of cultured plants as growth surfaces for nitrifying bacteria. During the study, the highest TAN concentrations were reached when the TAN concentrations peaked around day 7 and were around $25 \mathrm{mg} / \mathrm{dm}^{3}$ (tomato) and $32.5 \mathrm{mg} / \mathrm{dm}^{3}$ (pak choi). These concentrations are higher than those observed in the discussed experiment; moreover, they did not decrease to a similar degree in a comparable period of time. This difference is probably due to the smaller root surface area in relation to the effective surface of the applied biological filter medias.

According to Karpinski et al. [53], the increase in nitrite concentration is delayed in relation to the increase in ammonium concentration (Figures 4, 5, 7 and 8; Tables 1, 3 and 6a). In the conducted experiment, an increase in nitrite concentrations was observed from the beginning of the experiment (Figures 5 and 8). Initially, these concentrations were relatively low compared to the observed concentrations of ammonium nitrogen, however, since the growth curve is exponential, the concentration of nitrite increased very quickly (Table 6a). Subsequently, the increase in nitrite concentration slowed down and slightly collapsed, followed by a reversal of the trend observed in the first period. Nitrite concentrations in all RAS systems dropped rapidly, reaching a relatively constant level (Figures 5 and 8, Table 6a,b). This course of concentration changes was observed in all RAS systems except the system in which the failure occurred (Table 6a). In this system, the period of deceleration and collapse of the upward trend does not occur (Table 6b). Maximum concentration values were reached much faster and they began to decrease faster. This is reflected in the equations describing the course of nitrification (Table $6 a, b)$. The time needed to stabilize the second phase of nitrification ranged from 15 to 33 days (Figures 5 and 8). This is different from the results obtained by Kuhn et al. [45]. Despite the fact that measurements were carried out for 28 days, no downward trend was observed. This situation occurred in systems not inoculated with nitrifying bacteria. Different results were obtained in systems inoculated with nitrifiers-no increase in nitrite concentration was observed. In the research conducted by Sikora et al. [18], the time needed to stabilize the second phase of nitrification was 35 days, which is longer than the results observed in this article, although similar. Comparable times to those obtained during the experiment and to those obtained by Sikora et al. [18] were also obtained by Seo et al. [51] during an experiment with the acclimatization of nitrifiers to saltwater conditions. The acclimatization time of biological filters, and thus the time needed for nitrite oxidation to a safe level, was achieved after 33 days (salinity 7.5 and $15 \mathrm{ppt}$ ) and 39 days (salinity $30 \mathrm{ppt}$ ). Longer nitrite elimination times than observed during the experiment were also reported by $\mathrm{Hu}$ et al. [52]. The time needed for oxidation of nitrite to nitrate in aquaponic cultivation was about 40 and 50 days for tomato and pak choi respectively. As in the case of ammonia oxidation, the surface of the roots on which nitrifying bacteria developed was smaller than in the tested biological filter medias.

For nitrates, the recorded concentration values increased from the very beginning of the experiment. Initially, as with nitrites, this increase was slow to eventually accelerate. After a period of dynamic growth, nitrate concentrations stabilized (Figures 6 and 9; Table 7). For CF, despite the similar nature of the increase curve, the concentrations were higher during the first part of the experiment. No similar trend was observed for the same type of filter in the second part of the experiment (Figures 6 and 9). Higher values in the initial phase of growth in the second part of the experiment show the concentrations in the RAS system in which the failure occurred (Figure 9). The similar nature of the increase in nitrate concentration was reported by both Kuhn et al. [45] (circulation vaccinated with nitrifying bacteria) and Sikora et al. [18]. Kuhn et al. [45] did not observe an increase in the concentration of nitrates in the RAS system inoculated with nitrification, which was associated with the incomplete nitrification process. The nitrate concentration increase curve presented by Seo et al. [51] was comparable to the present experiment. At the end of the experiment, a decrease in nitrate concentration was observed in individual RAS systems. Probably this decrease was associated with the development of heterotrophic bacteria in the volume of water. 
During this experiment, it was analysed how the concentrations of nitrogen forms in water are shaped in experimental RAS systems. On this basis, the course of the nitrification process was determined along with the time needed for the biological filter to mature. The maturation of the biological filter is largely dependent on the temperature at which the process takes place (Table 8). In systems using cool water, a mature filter can be obtained after a few months of its work, while this period is significantly shorter in systems developed for the needs of thermophilic species. Another factor that may affect the maturation of biological filters is the presence of the desired nitrifying bacteria. Biological filters inoculated with nitrifying bacteria, operating at $25^{\circ} \mathrm{C}$, show desirable properties after 53 days [54]. The use of water from tilapia culture (temperature $26.4^{\circ} \mathrm{C}$ ) allowed a functional biological filter to be obtained after 56 days [5]. These results do not reflect the information provided by Kolman [55], who states that at $18{ }^{\circ} \mathrm{C}$, it takes 40 to 60 days to obtain a working biological filter. In addition, the periods given differ from those obtained by Sikora et al. [18]. Studies have shown that the time needed to mature a biological filter without inoculating the culture cycle with nitrifying bacteria cultures is 35 days at $23^{\circ} \mathrm{C}$.

Table 8. Comparison of time needed to mature biological filter in accordance with temperature on the example of literature data and conducted experiment: PPA-polypropylene aggregate, PSC—polyethylene screw caps for PET bottles, CF-commercial fittings HXF12KLL, CFsf-control submerged filter for dripping filters, commercial fittings HXF12KLL.

\begin{tabular}{|c|c|c|c|c|c|}
\hline & & $\begin{array}{c}\text { Temperature } \\
\left({ }^{\circ} \mathrm{C}\right)\end{array}$ & Time (d) & ${ }^{\circ} \mathbf{D}$ & Source of Biogens \\
\hline Sanc & al., 2002 & 25.0 & 53 & 1325 & No data \\
\hline Greiner a & immons, 1998 & 26.4 & 56 & 1478.4 & Fish \\
\hline & n, 2002 & 18.0 & $40-60$ & $720-1080$ & No data \\
\hline \multirow{8}{*}{ This paper } & al. 2018 & 23.0 & 35 & 805 & Fish \\
\hline & Submerged, PPA & 25.0 & 35 & 875 & Fish \\
\hline & Submerged, PSC & 25.0 & 36 & 900 & Fish \\
\hline & Submerged, CF & 25.0 & 21 & 525 & Fish \\
\hline & Dripping PPA & 25.0 & 37 & 924 & Fish \\
\hline & Dripping PSC & 25.0 & 32 & 800 & Fish \\
\hline & Submerged CFsf & 25.0 & 18 & 700 & Fish \\
\hline & Dripping CF & 25.0 & 18 & 450 & Fish \\
\hline
\end{tabular}

The conducted tests showed that at $25^{\circ} \mathrm{C}$, without introducing nitrifying bacteria cultures into the RAS system, the time needed for the filter to mature is from 21 to 33 days. If nitrifying bacteria are present, this period may be shorter. In one of the RAS systems used for the experiment, a failure occurred. As a result of the failure, it was necessary to restart the RAS. This RAS was dried and disinfected in accordance with the adopted procedure. In this system (drip filter, CF), a functional biological filter was obtained on day 16 .

\section{Conclusions}

The maturation of biological filters is, despite the overall repetitive pattern, a largely variable process. The time of individual stages of nitrification and their courses differ. It largely depends on the type of filter used and its filling and prevailing conditions. The obtained results showed the effectiveness of all tested biofilter media. The shortest time to biofilter maturation was when submerged $\mathrm{CF}$ was used. However, the maximum peak concentration of nitrite was also noted when it was used. For fish culture welfare, it is important that nitrite concentration should be as low as possible. Therefore, other tested biofilter media worked better from this point of view. New technologies are being sought, new materials are used as filter fillings and nitrification conditions are being modified. Increasingly, breeders want to increased production faster and faster. This involves the use of increasingly efficient filters that can be run faster. Research such as that described in this article is helpful, even necessary, 
in learning how the nitrification process works, the conditions that shape it and what should be done to obtain fully efficient biological filters.

In addition, the article describes an unorthodox approach to new materials useful as cartridges for biological filters. Both PPA and PSC are materials that are associated as a convenient intermediate, not a useful cartridge for biological filters. However, these materials proved to be effective within the assumed parameters.

Author Contributions: The following statements should be used “Conceptualization, M.S., D.K.; Methodology, M.S., J.N.; Software, M.S.; Validation, M.S., J.N.; Formal Analysis, M.S.; Investigation, M.S.; Resources, M.S., D.K., J.N.; Data Curation, M.S.; Writing-Original Draft Preparation, M.S.; Writing-Review \& Editing, M.S., J.N., D.K.; Visualization, M.S.; Supervision, D.K.; Project Administration, D.K. All authors have read and agreed to the published version of the manuscript.

Funding: This research was funded by UWM Olsztyn, project No. 18.610.005-110 and the project was financially supported by Minister of Science and Higher Education in the range of the program entitled "Regional Initiative of Excellence" for the years 2019-2022, Project No. 010/RID/2018/19, amount of funding 12.000.000 PLN.

Conflicts of Interest: The authors declare no conflict of interest.

\section{References}

1. FAO. HLEF2050 Global Agriculture. 2016. Available online: http://www.fao.org/fileadmin/templates/wsfs/ docs/Issues_papers/HLEF2050_Global_Agriculture.pdf (accessed on 10 March 2016).

2. FAO. The State of World Fisheries and Aquaculture, Contributing to Food Security and Nutrition for All; Food and Agriculture Organization of the United Nations: Rome, Italy, 2016.

3. Timmons, N.; Timmons, M.B.; Ebeling, J.M. Recirculating Aquaculture System (RAS) Technologies. Aquac. Mag. 2006, 32, 32-39.

4. Kristensen, T.; Åtland, Å; Rosten, T.; Urke, H.A.; Rosseland, B.O. Important influent-water quality parameters at freshwater production sites in two salmon producing countries. Aquac. Eng. 2009, 41, 53-59. [CrossRef]

5. Greiner, A.D.; Timmons, M.B. Evaluation of the nitrification rates of microbead and trickling filters in an intensive recirculating tilapia production facility. Aquac. Eng. 1998, 18, 189-200. [CrossRef]

6. Chen, S.; Ling, J.; Blancheton, J.P. Nitrification kinetics of biofilm as affected by water quality factors. Aquac. Eng. 2006, 34, 179-197. [CrossRef]

7. Emparanza, E.J.M. Problems affecting nitrification in commercial RAS with fixed-bed biofilters for salmonids in Chile. Aquac. Eng. 2009, 41, 91-96. [CrossRef]

8. Eding, E.H.; Kamstra, A.; Verreth, J.A.J.; Huisman, E.A.; Klapwijk, A. Design and operation of nitrifying trickling filters in recirculating aquaculture: A review. Aquac. Eng. 2006, 34, 234-260. [CrossRef]

9. Wicks, B.J.; Joensen, R.; Tang, Q.; Randall, D.J. Swimming and ammonia toxicity in salmonids: The effect of sub lethal ammonia exposure on the swimming performance of coho salmon and the acute toxicity of ammonia in swimming and resting rainbow trout. Aquat. Toxicol. 2002, 59, 55-69. [CrossRef]

10. Randall, D.J.; Tsui, T.K.N. Ammonia toxicity in fish. Marine Pollut. Bull. 2002, 45, 17-23. [CrossRef]

11. Thurston, R.V.; Russo, R.C. Acute toxicity of ammonia to rainbow trout. Trans. Am. Fish. Soc. 1983, 112, 696-704. [CrossRef]

12. Thurston, R.V.; Russo, R.J.; Luedtke, R.J.; Smith, C.E.; Meyn, E.L.; Chakoumalos, C.; Wang, K.C.; Brown, C.J.D. Chronic toxicity of ammonia to rainbow trout. Trans. Am. Fish. Soc. 1984, 113, 56-73. [CrossRef]

13. Wood, C.M. Toxic responses of the gill. In Target Organ Toxicity in Marine and Freshwater Teleosts; Schlenk, D., Benson, W.H., Eds.; Taylor \& Francis: London, UK, 2001; Volume 1, pp. 1-89.

14. Cheng, W.; Hsiao, I.S.; Chen, J.C. Effect of nitrite on immune response of Taiwan abalone Haliotis diversicolor supertexta and its susceptibility to Vibrio parahaemolyticus. Dis. Aquat. Org. 2004, 60, 157-164. [CrossRef] [PubMed]

15. Miron, D.S.; Moraes, B.; Becker, A.G.; Crestani, M.; Spanevello, R.; Loro, V.L.; Baldisserotto, B. Ammonia and $\mathrm{pH}$ effects on some metabolic parameters and gill histology of silver catfish, Rhamdiaquelen (Heptapteridae). Aquaculture 2008, 277, 192-196. [CrossRef]

16. Benli, A.C.K.; Köksal, G.; Özkul, A. Sublethal ammonia exposure of Nile tilapia (Oreochromis niloticus L.): Effects on gill, liver and kidney histology. Chemosphere 2008, 72, 1355-1358. [CrossRef] [PubMed] 
17. Hurtado, C.F.; Cancino-Madariaga, B. Ammonia retention capacity of nanofiltration and reverse osmosis membranes in a non-steady state system, to be use in recirculation aquaculture systems (RAS). Aquac. Eng. 2014, 58, 29-34. [CrossRef]

18. Sikora, M.; Nowosad, J.; Biegaj, M.; Kucharczyk, D.; Debowski, M. The possibility of application of agglomerate elastomers (EPP) as media for biological bed in aquaculture. Aquac. Res. 2018, 49, $2988-2994$. [CrossRef]

19. Zhu, S.; Chen, S. The impact of temperature on nitrification rate in fixed film biofilters. Aquac. Eng. 2002, 26, 221-237. [CrossRef]

20. Suhr, K.I.; Pedersen, P.B. Nitrification in moving bed and fixed bed biofilters treating effluent water from a large commercial outdoor rainbow trout RAS. Aquac. Eng. 2010, 42, 31-37. [CrossRef]

21. Hamlin, H.J. Nitrate toxicity in Siberian sturgeon (Acipenser baeri). Aquaculture 2006, 253, 688-693. [CrossRef]

22. Malone, R.F.; Pfeiffer, T.J. Rating fixed-film nitrifying biofilters used in recirculating aquaculture systems. Aquac. Eng. 2006, 34, 389-402. [CrossRef]

23. Camargo, J.A.; Alonso, A.; Salamanca, A. Nitrate toxicity to aquatic animals: A review with new data for freshwater invertebrates. Chemosphere 2005, 58, 1255-1267. [CrossRef]

24. Badiola, M.; Mendiola, D.; Bostock, J. Recirculating Aquaculture Systems (RAS) analysis: Main issues on management and future challenges. Aquac. Eng. 2012, 51, 26-35. [CrossRef]

25. Ling, J.; Chen, S. Impact of organic carbon on nitrification performance of different biofilters. Aquac. Eng. 2005, 33, 150-162. [CrossRef]

26. Guedart, T.C.; Losordo, T.M.; Classen, J.J.; Osborne, J.A.; DeLong, D.P. An evaluation of commercially available biological filters for recirculating aquaculture systems. Aquac. Eng. 2010, 42, 38-49. [CrossRef]

27. Guedart, T.C.; Losordo, T.M.; Classen, J.J.; Osborne, J.A.; De Long, D.P. Evaluating the effects of organic carbon on biological filtration performance in a large scale recirculating aquaculture system. Aquac. Eng. 2011, 44, 10-18. [CrossRef]

28. Kucharczyk, D.; Targońska, K.; Hliwa, P.; Gomułka, P.; Kwiatkowski, M.; Krejszeff, S.; Perkowski, J. Reproductive parameters of common carp (Cyprinus carpio L.) spawners during natural season and out-of-season spawning. Reprod. Biol. 2008, 8, 285-289. [CrossRef]

29. Kucharczyk, D.; Nowosad, J.; Łuczyński, M.J.; Targońska, K. New technique for fertilizing eggs of burbot, asp and ide under hatchery conditions. Anim. Reprod. Sci. 2016, 172, 143-147. [CrossRef]

30. Nowosad, J.; Kucharczyk, D.; Biłas, M.; Palińska-Żarska, K.; Krejszeff, S. Optimization of feeding rate of juvenile common carp, (Cyprinus carpio L.), during short intensive rearing under controlled conditions. Experiment 2013, 15, 1056-1063.

31. Nowosad, J.; Żarski, D.; Biłas, M.; Dryl, K.; Krejszeff, S.; Kucharczyk, D. Dynamics of ammonia excretion in juvenile common tench, Tincatinca (L.), during intensive rearing under controlled conditions. Aquac. Int. 2013, 21, 629-637. [CrossRef]

32. Svobodová, Z.; Máchová, J.; Poleszczuk, G.; Hòda, J.; Hamáâková, J.; Kroupová, H. Nitrite poisoning of fish in aquaculture facilities with water-recirculating systems. Acta Vet. Brno 2005, 74, 129-137. [CrossRef]

33. Kuhn, D.D.; Smith, S.A.; Boardman, G.D.; Angier, M.W.; Marsh, L.; Flick, G.J., Jr. Chronic toxicity of nitrate to Pacific white shrimp. Litopenaeus vannamei: Impacts on survival, growth, antennae length, and pathology. Aquaculture 2010, 309, 109-114. [CrossRef]

34. Tanikawa, D.; Nakamura, Y.; Tokuzawa, H.; Hirakata, Y.; Hatamoto, M.; Yamaguchi, T. Effluent treatment in an aquaponics-based closed aquaculture system with single-stage nitrification-denitrification using a down-flow hanging sponge reactor. Int. Biodeterior. Biodegrad. 2018, 132, 268-273. [CrossRef]

35. Losordo, T.M.; Hobbs, A.O. Using computer spreadsheets for water flow and biofilter sizing in recirculating aquaculture production systems. Aquac. Eng. 2000, 23, 95-102. [CrossRef]

36. Crab, R.; Avnimelech, Y.; Defoirdt, T.; Bossier, P.; Verstraete, W. Nitrogen removal techniques in aquaculture for sustainable production. Aquaculture 2007, 270, 1-14. [CrossRef]

37. Hargrove, L.L.; Westerman, P.W.; Losordo, T.M. Nitrification in three-stage and single-stage floating bead biofilters in a laboratory-scale recirculating aquaculture system. Aquac. Eng. 1996, 15, 67-80. [CrossRef]

38. van Rijn, J. The potential for integrated biological treatment systems in recirculating fish culture. Rev. Aquac. 1996, 139, 181-201. [CrossRef] 
39. Ridha, M.T.; Cruz, E.M. Effect of biofilter media on water quality and biological performance of the Nile tilapia Oreochromis niloticus L. reared in a simple recirculating system. Aquac. Eng. 2001, 24, 157-166. [CrossRef]

40. Zhu, S.; Chen, S. An experimental study on nitrification biofilm performances using a series reactor system. Aquac. Eng. 1999, 20, 245-259. [CrossRef]

41. Żarski, D.; Kucharczyk, D.; Targoñska, K.; Chyła, B.; Dobrołowicz, A. Dynamics of changes in nitrogen and phosphorus compounds during intensive rearing of ide, leuciscusidus (L.), in a recirculating system. Arch. Pol. Fish. 2008, 16, 459-467. [CrossRef]

42. Żarski, D.; Kucharczyk, D.; Targońska, K.; Krejszeff, S.; Czarkowski, T.; Babiarz, E.; Nowosielska, D.B. Dynamics of nitrogen and phosphorus in closed and semi-closed recirculating aquaculture systems during the intensive culture of goldfish, Carassius auratus auratus (L.), juveniles. Arch. Pol. Fish. 2010, 18, 187-193. [CrossRef]

43. Ebeling, J. Biofiltration. In Presentation Notebook of the Aquacultural Engineering Society Workshop; Intensive Fin-fish Systems and Technologies: Orlando, FL, USA, 2001; pp. 47-56.

44. Itoi, S.; Ebihara, N.; Washio, S.; Sugita, H. Nitrite-oxidizing bacteria, nitrospira, distribution in the outer layer of the biofilm from filter materials of a recirculating water system for the goldfish Carassius auratus. Aquaculture 2007, 264, 297-308. [CrossRef]

45. Kuhn, D.D.; Drahos, D.D.; Marsh, L.; Flick, G.J., Jr. Evaluation of nitrifying bacteria product to improve nitrification efficacy in recirculating aquaculture systems. Aquac. Eng. 2010, 43, 78-82. [CrossRef]

46. Pulkkinen, J.T.; Eriksson-Kallio, A.M.; Aalto, S.L.; Tiirola, M.; Koskela, J.; Kiuru, T.; Vielma, J. The effects of different combinations of fixed and moving bed bioreactors on rainbow trout (Oncorhynchus mykiss) growth and health, water quality and nitrification in recirculating aquaculture systems. Aquac. Eng. 2019, 85, 98-105. [CrossRef]

47. Davidson, J.; Good, C.; Williams, C.; Summerfelt, S.T. Evaluating the chronic effects of nitrate on the health and performance of post-smolt Atlantic salmon Salmo salar in freshwater recirculation aquaculture systems. Aquac. Eng. 2017, 79, 1-8. [CrossRef]

48. Hamlin, H.J.; Michaels, J.T.; Beaulaton, C.M.; Graham, W.F.; Dutt, W.; Steinbach, P.; Losordo, T.M.; Schrader, K.K.; Main, K.L. Comparing denitrification rates and carbon sources in commercial scale upflow denitrification biological filters in aquaculture. Aquac. Eng. 2008, 38, 79-92. [CrossRef]

49. delos Reyes, A.A., Jr.; Lawson, T.B. Combination of a bead filter and rotating biological contactor in a recirculating fish culture system. Aquac. Eng. 1996, 15, 27-39. [CrossRef]

50. Barak, Y.; van Rijn, J. Biological phosphate removal in a prototype recirculating aquaculture treatment system. Aquac. Eng. 2000, 22, 121-136. [CrossRef]

51. Seo, J.-K.; Jung, I.-H.; Kim, M.-R.; Kim, B.J.; Nam, S.-W.; Kim, S.-K. Nitrification performance of nitrifiers immobilized in PVA (polyvinyl alcohol) for a marine recirculating aquarium system. Aquac. Eng. 2001, 24, 181-194. [CrossRef]

52. Hu, Z.; Lee, J.W.; Chandran, K.; Kim, S.; Brotto, A.C.; Khanal, S.K. Effect of plant species on nitrogen recovery in aquaponics. Bioresour. Technol. 2015, 188, 92-98. [CrossRef]

53. Karpiński, A.; Szkudlarek, M.; Zakęś, Z. Nitrification in recirculation systems. Practical remarks about maturation of the biologically active filter. Komunikaty Rybackie 1999, 3, 11-14. (In Polish)

54. Sandu, S.I.; Boardman, G.D.; Watten, B.J.; Brazil, B.L. Factors influencing the nitrification efficiency of fluidized bed filter with a plastic bead medium. Aquac. Eng. 2002, 26, 41-59. [CrossRef]

55. Kolman, R. Effectiveness of a biological shelf filter used to treat water in a recirculation system during trout rearing. Arch. Pol. Fish. 1992, 1 (Suppl. 1), 1-37. (In Polish)

(C) 2020 by the authors. Licensee MDPI, Basel, Switzerland. This article is an open access article distributed under the terms and conditions of the Creative Commons Attribution (CC BY) license (http://creativecommons.org/licenses/by/4.0/). 